\title{
Experiments on the Rearing of Fish Larvæ in the Season of 1894.
}

$\mathrm{By}$

\author{
J. T. Cumningham, M.A., \\ Naturalist to the Association.
}

IT may be useful to put on record the following notes of renewed attempts to solve the difficult problem of rearing fish larvæ.

On January 23rd a large number of eggs were observed in one of the aquarium tanks which contained several whiting. The eggs were collected and placed in a hatching jar, and began to hatch on January 29th. I prepared a small tank in the Laboratory for rearing the larva. The outflow pipe was protected by placing over it an inverted hatching-jar, open at both ends and resting on a layer of sand and gravel. The water was supplied to the tank by a solid carbon block filter attached to one of the jets. The inflow of water was very slow indeed. The temperature in the tank on February 3rd was $12^{\circ} \mathrm{C}$., and on this date the larvæ in the tank were healthy, having the jaws developed, but the yolk not yet all absorbed. One lot of larvæ were put into the tank on January 30th, a second lot on February 1st. On February 4th I put in some fine particles of worm food, that is to say, ovarian eggs of Nereis obtained by mincing the worms and then separating the eggs by decantation. On the 5th, as the larvæ did not seem to take the worm-food readily, I put in some tow-net collections strained through fine boltting cloth so as to exclude the larger animals. Then I saw the larvæ pecking at this food, and in one I took out I found (in the stomach) a Gasteropod larva with spiral shell. On the 6th I put in a little of both kinds of food, and observed that the larvæ preferred the pelagic material, but they did not feed vigorously on either kind. On the 7th I examined a few, and found the stomachs of most of them empty and dilated, but in one was a small Copepod. On the 8th the number of the larvæ was diminished; on the 9 th very few were to be seen, and on the 10th none were found. In the course of this experiment I found that when the supply of water was very much reduced on account of the choking of the char- 
coal filter a scum of bacteria in the zooglœa form soon appeared on the surface. I therefore replaced the charcoal filter by sand filters made in a box or bottle, during the whole experiment supplying water only through some kind of effective filter.

On March 10th flounder and plaice eggs were first seen at the surface of the large tank, containing flat-fishes, in the aquarium. On the 12th I collected a considerable number and put them in a hatching jar, and shortly afterwards placed others in a second hatching jar. It was not practicable to separate the larger plaice eggs from the smaller ones of the flounder. On the 19th the flounder eggs were found to be hatched; the plaice larvæ began to emerge on the $22 n d$, and on the 24th I turned all the larvæ out into one of the Laboratory tanks, the inflow of water passing through a filter of sand and gravel contained in a glass jar. I fed them as usual, partly with eggs of Nereis, partly with strained material from the tow-nets. On the same day I put some of the larvæ into a bell-jar filled with water brought in from the open sea. In the tank, in addition to the inflow of water I arranged a delivery of air in small bubbles at the bottom of the tank, thinking that this would serve two purposes, to aërate the water and to keep the food-particles suspended.

The plaice larvæ lost the yolk and began to feed on March 27th. They took the worm food more readily than the living material from the tow-nets. On April 2nd they were nine days old, and at this time the very fine primordial rays had appeared in the posterior part of the larval median fin membrane. On April 9th there were not many surviving, and in these no great advance in development was visible, but the commencement of the formation of the permanent caudal fin was indicated. The number steadily diminished, and the last specimen was seen on April 23rd, when it was thirty days old. In these older specimens the formation of the permanent fin-rays had not commenced, still less had the rotation of the eyes begun to take place.

The larvæ in the bell-jar in water from the open sea lived a much shorter time; the last was seen on April 1st.

Another lot of plaice larvæ were hatched on April 9th, and I turned them out into one of the Laboratory tanks supplied with water directly from a jet without filtration, and I provided no air supply. I fed these very carefully on the usual worm food, which they took readily. I carefully washed the food, so as to keep out as much as possible the blood and soluble matters derived from the worms. These larvæ began to die off as usual after some days, but two were seen alive on May 16th, when they were thirty-seven days old, or five weeks and two days, which is a much longer period than I have succeeded in keeping them before. 